\title{
Exoskeletal abnormalities in paradoxidid trilobites from the Cambrian of Spain, and a new type of bite trace
}

\author{
SAMUEl ZAMORA, EduARdO MAYORAL, JORGE ESTEVE, JOSÉ ANTONIO GÁMEZ VINTANED \& \\ ANA SANTOS
}

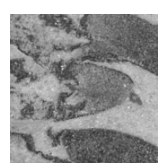

\begin{abstract}
Exoskeletal abnormalities in middle Cambrian paradoxidid trilobites from Purujosa (Eastern Iberian Chain, NE Spain) are herein analyzed for the first time. Two distinct types are reported. The first is represented by triangular or asymmetrical V- to W-shaped breaks on margins of isolated sclerites (cranidia, free cheeks and hypostomes). The second group is represented by shortened thoracic pleural spines in complete or nearly complete individuals. Possible causes of these injuries are discussed, but in some cases a single cause/effect explanation is not apparent. A new ichnotaxon, Mandibulichnus serratus nov. ichnogen., nov. ichnosp., is erected to refer to serrated breakage of the margins of isolated trilobite sclerites produced by active predation or scavenging. • Key words: Durophagous predation, Mandibulichnus serratus nov. ichnogen., nov. ichnosp., Cambrian, trilobites, Spain.
\end{abstract}

Zamora, S., Mayoral, E., Esteve, J., GÁmez Vintaned, J.A. \& SANTOS, A. 2011. Exoskeletal abnormalities in paradoxidid trilobites from the Cambrian of Spain, and a new type of bite trace. Bulletin of Geosciences 86(3), 665-673 (4 figures, 2 tables). Czech Geological Survey, Prague. ISSN 1214-1119. Manuscript received December 17, 2010; accepted in revised form June 30, 2011; published online July 29, 2011; issued September 30, 2011.

Samuel Zamora, Department of Palaeontology, The Natural History Museum, Cromwell Road, SW7 5BD London, UK; samuel@unizar.es・Eduardo Mayoral \& Ana Santos, Departamento de Geodinámica y Paleontología, Facultad de Ciencias Experimentales, Campus de El Carmen, Universidad de Huelva, Avda. Tres de Marzo, s/n. E-21071 Huelva (Spain); mayoral@uhu.es, asantos@dgyp.uhu.es・Jorge Esteve, Departamento de Ciencias de la Tierra e Instituto de Investigación en Ciencias Ambientales de Aragón, Universidad de Zaragoza, Pedro Cerbuna 12, E-50009 Zaragoza, Spain; jorgeves@unizar.es•José Antonio Gámez.Vintaned, Departamento de Geología, Universitat de València, C/Dr. Moliner 50,E-46100 Burjassot, Valencia, Spain; gamez@unizar.es

The widespread occurrence of metazoans with mineralized skeletons since the Cambrian provides us with the opportunity to uncover evidence of predation and skeletal malformations (including bite traces and healing structures) in preyed upon animals with exoskeletons (Hutchinson 1961, Vermeij 1989). Trilobites have an excellent fossil record and a broad geographical distribution; as a result they are an ideal group in which to analyze such exoskeletal abnormalities. There are many different works focussed on trilobite malformations (e.g. Šnajdr 1978, 1979; Owen 1985; Babcock 1993; Fatka et al. 2009; Budil et al. 2010); among these, predation or scavenging breakages are the most commonly reported traces on the exoskeleton (Šnajdr 1978, Briggs \& Mount 1982, Owen 1985, Babcock 1993, Pratt 1998). Their presence is highly significant as it provides evidence for predator-prey relationships and the structure of food webs in ancient ecosystems (Babcock 2003).

Potential predators of trilobites were present in the lower Cambrian, but they did not become abundant and di- verse until the middle Cambrian (Babcock 2003). Anomalocaridid arthropods (such as Anomalocaris, Hurdia, Laggania and Stanleycaris) were probably the largest predators of the Cambrian seas, and are thought to have had an important impact on ecological structuring in the first complex marine communities (Daley et al. 2009). There are several examples of predation scars from the lower and middle Cambrian that have been attributed to anomalocaridids (Rudkin 1979, Briggs \& Mount 1982, Babcock \& Robison 1989, Babcock 1993); however, many Cambrian arthropods were probably predators or scavengers at some point during their lifecycle (Vannier et al. 2009), and thus potential producers of the breakages described on trilobite exoskeletons (Pratt 1998). Furthermore, the differences between predation scars and breakages produced by scavengers are sometimes impossible to discern.

Non-predational malformations in trilobites could be inherited disorders, or related to the moulting process, copulation or even combat (Owen 1985, Rudkin 1985) - in 


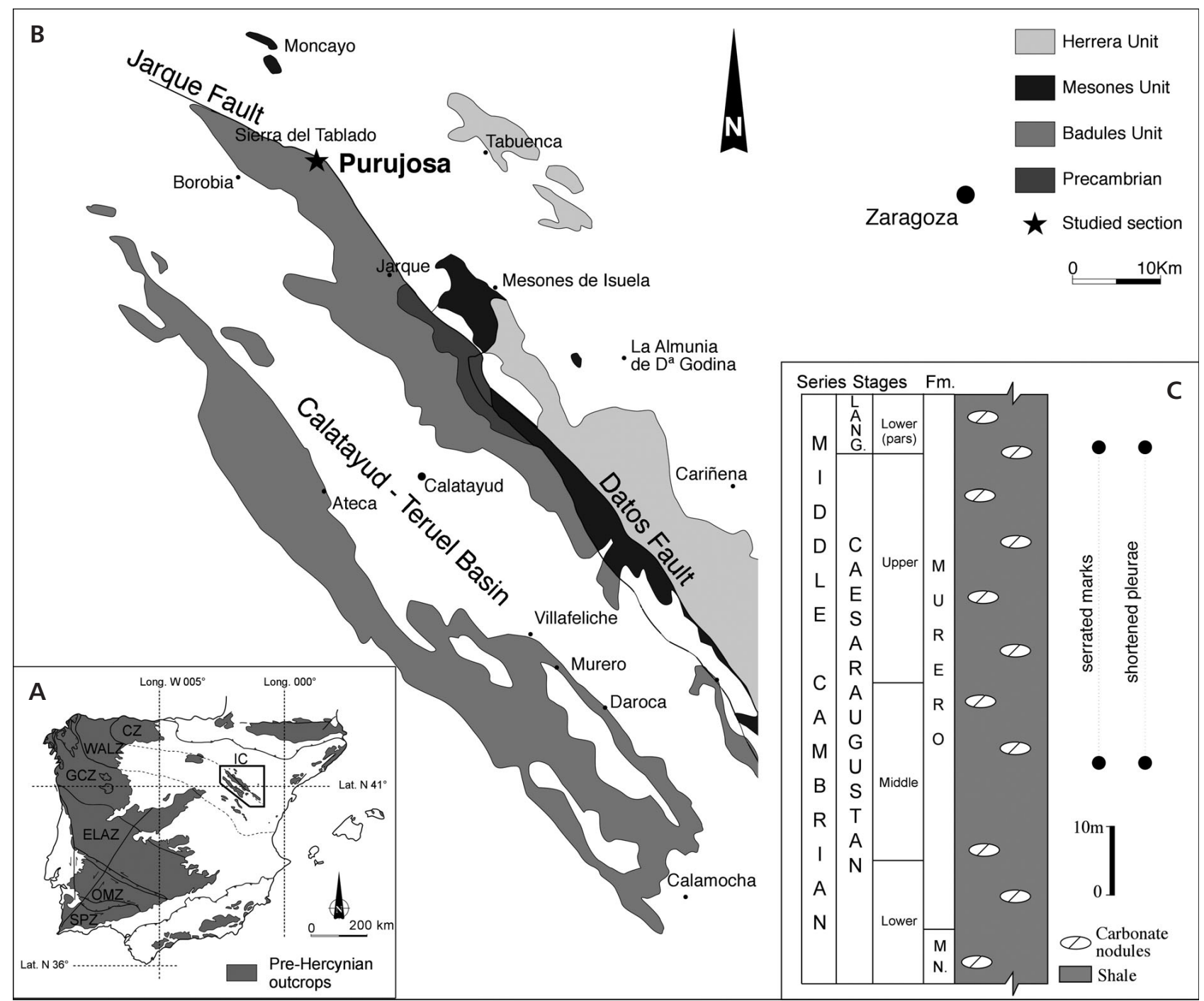

Figure 1. A - map of Spain with the location of the Iberian Chains. $\bullet$ B - map showing study locality in the northern part of the Eastern Iberian Chain (NE Spain), after Gozalo \& Liñán (1988). • C - synthetic stratigraphic column from Purujosa showing the levels from which the specimens were collected. Abbreviations: CZ - Cantabrian Zone; ELAZ - East Lusitanian-Alcudian Zone; GCZ - Galician-Castilian Zone; IC - Iberian Chains; OMZ - Ossa-Morena Zone; SPZ - South Portuguese Zone; WAL - West Asturian-Leonese Zone; LANG - Languedocian; MN - Mansilla; Fm. - Formation.

many cases, it is difficult to ascertain their precise cause (e.g., Budil et al. 2010).

The objectives of this study are threefold: (1) to report the first evidence of trilobite exoskeletal abnormalities represented by serrated sclerite margins and shortened pleural spines in middle Cambrian paradoxidids from the Eastern Iberian Chain (NE Spain), (2) to characterize and interpret these abnormalities, and (3) to treat them from an ichnotaxonomical point of view. It is important to note that the majority of the examples reported herein come from a single stratigraphic level which yielded over 570 complete paradoxidid specimens, providing important insights into the relative abundance of these abnormalities in the Cambrian fossil record.

\section{Geographic and geological setting}

Specimens were collected from the Purujosa 3 section ( $2 \mathrm{~km}$ south of Purujosa village, Zaragoza province), inside the limits of the Moncayo Natural Park, northern tip of the Eastern Iberian Chain (Northeast Spain, Fig. 1A, B). This section encompasses most of the Murero Formation (which yielded all of the specimens described in this paper) and its transition into the Borobia Formation (Fig. 1C).

The Murero Formation consists of siliciclastic shales with interbedded carbonate nodules (Liñán et al. 2002), and has been interpreted as being deposited in transgressive conditions of offshore environments (Álvaro \& Vennin 1997, Gámez Vintaned et al. 2009). The majority of paradoxidid specimens come from the uppermost 
red-coloured shales of the upper Murero Formation, and were recovered along with hundreds of other complete trilobites, many of which are fully enrolled (see Esteve et al. 2011). This includes redlichids (Eccaparadoxides), ptychoparids (Solenopleuropsis, Conocoryphe, and a new alokistocarid) and agnostids (Peronopsis, Megagnostus, Condylopyge and Plaurocterium). All of the above mentioned genera have been found articulated with the exception of Condylopyge and Plaurocterium, which together represent only a small percentage of the entire assemblage. Other fossil components include protorthacean and lingulid brachiopods, sponges and echinoderms. Echinoderm assemblages from the uppermost red shales are more diverse than in any other Cambrian locality known (Zamora 2010, Zamora \& Smith 2010, Zamora \& Álvaro 2010). They include the cinctan Gyrocystis platessa, the eocrinoids Gogia gondi and a new Lichenoididae, the stylophorans Ceratocystis sp. and two different undescribed cothurnocystids, a new group of pelmatozoans informally called "dibrachicystids" and rare isorophid edrioasteroids belonging to a newly described genus Protorophus Zamora and Smith, 2010. Fossils from this section are not tectonically distorted, but are sometimes flattened due to compression.

The age of the Murero Formation in the study area ranges from lower Caesaraugustan to lower Languedocian; the red shale level is lower Languedocian, belonging to the Solenopleuropsis thorali Zone (sensu Álvaro \& Vizcaïno 1998). Correlation with the global stages proposed by the ISCS suggests these levels belong to Cambrian Series 3, Stage 5 (based on chemostratigraphic data from Álvaro et al. 2008); however, see Gozalo et al. in this volume for alternatives.

\section{Material and methods}

All the specimens studied and illustrated herein are housed in the Museo Paleontológico de la Universidad de Zaragoza (MPZ), Spain, under repository numbers MPZ 2006/375 and MPZ 2010/922 to MPZ 2010/938 (Tables 1, 2).

Fieldwork in the red shale levels of the Murero Formation indicates that a very low percentage of complete trilobites bear shortened pleural spines (six specimens out of a total of 453 articulated specimens). In contrast, isolated trilobite fragments with $\mathrm{V}$ - to $\mathrm{W}$-shaped breakages are slightly more common (25 specimens out of a total of 222 disarticulated sclerites). A few specimens from the same locality in existing Museum collections (MPZ) are incorporated in the present study, but these have not been used to calculate the relative abundance of sclerite damage per level because their precise horizon is unknown (Tables 1,2).

The trilobites are preserved as natural moulds occa-
Table 1. List of studied material and figured specimens bearing serrated margins.

\begin{tabular}{llcccl}
\hline $\begin{array}{l}\text { Repository } \\
\text { number }\end{array}$ & $\begin{array}{l}\text { Anatomic } \\
\text { component }\end{array}$ & $\begin{array}{l}\text { Width } \\
(\mathrm{mm})\end{array}$ & Angle & Figure & Type \\
\hline MPZ2010/922 & Cranidium & 6.7 & 85 & Fig 2A, D Acute \\
MPZ2010/923 & Librigena? & 2.7 & 70 & Fig 2B, E & Acute \\
MPZ2010/923 & Librigena? & 6.5 & 75.8 & Fig 2B, E & Acute \\
MPZ2010/924 & Cranidium & 6.1 & 72 & Fig 2C & Acute \\
MPZ2010/924 & Cranidium & 5 & 87 & Fig 2C & Acute \\
MPZ2010/925 & Uncertain & 2.5 & 66 & Fig 2F & Acute \\
MPZ2010/926 & Cranidium & 3.1 & 80 & - & Acute \\
MPZ2010/927 & Librigena & 5.3 & 100 & - & Acute \\
MPZ2010/928 & Anterior part & & & & Acute \\
& of librigena & 14 & 120 & - & \\
or cranidium & & & & \\
MPZ2010/929 & Librigena? & 2.7 & 125 & - & Acute \\
MPZ2010/930 & Hypostome? & 6.7 & 125 & - & Acute \\
MPZ2010/931 & Hypostome & - & - & - & Rounded \\
MPZ2010/932 & Uncertain & 1.1 & 127 & - & Acute \\
MPZ2010/933 & Cranidium & 4.2 & 127 & - & Acute \\
MPZ2010/934 & Librigena & & - & - & Rounded \\
\hline
\end{tabular}

sionally coated with clay minerals derived from the original exoskeleton, and were studied either directly from the rock matrix or from latex casts. They were examined under a stereomicroscope (Leica M165C) equipped with a camera lucida and imaged with a Nikon D80 digital camera. Length, width and angular measurements of the abnormalities were made using ImageJ (Abràmoff et al. 2004).

\section{Description and interpretation of abnormalities}

Owen (1985) suggested that skeletal abnormalities in trilobites may be the result of: (1) injuries, (2) teratological phenomena, and (3) pathological conditions. Injuries are caused by the physical breakage of the exoskeleton. Evidence of healed injuries includes cicatrisation, callus formation and partial regeneration (see Owen 1985 for full explanations of each term). Teratological phenomena are the result of genetic or developmental abnormalities, but the differences between these and injuries or pathological causes are sometimes impossible to ascertain (Owen 1985, Babcock 1993). Pathological conditions are the result of disease or parasitism, but only the later is detectable in trilobites (e.g. Šnajdr 1990, p. 63).

Herein, we describe the morphology of two different types of abnormalities in paradoxidid trilobites from NE Spain. The first comprises serrated breakage on the margins of isolated sclerites; the second is represented by shortened thoracic pleural spines. Possible causal mechanisms are discussed for each type. 


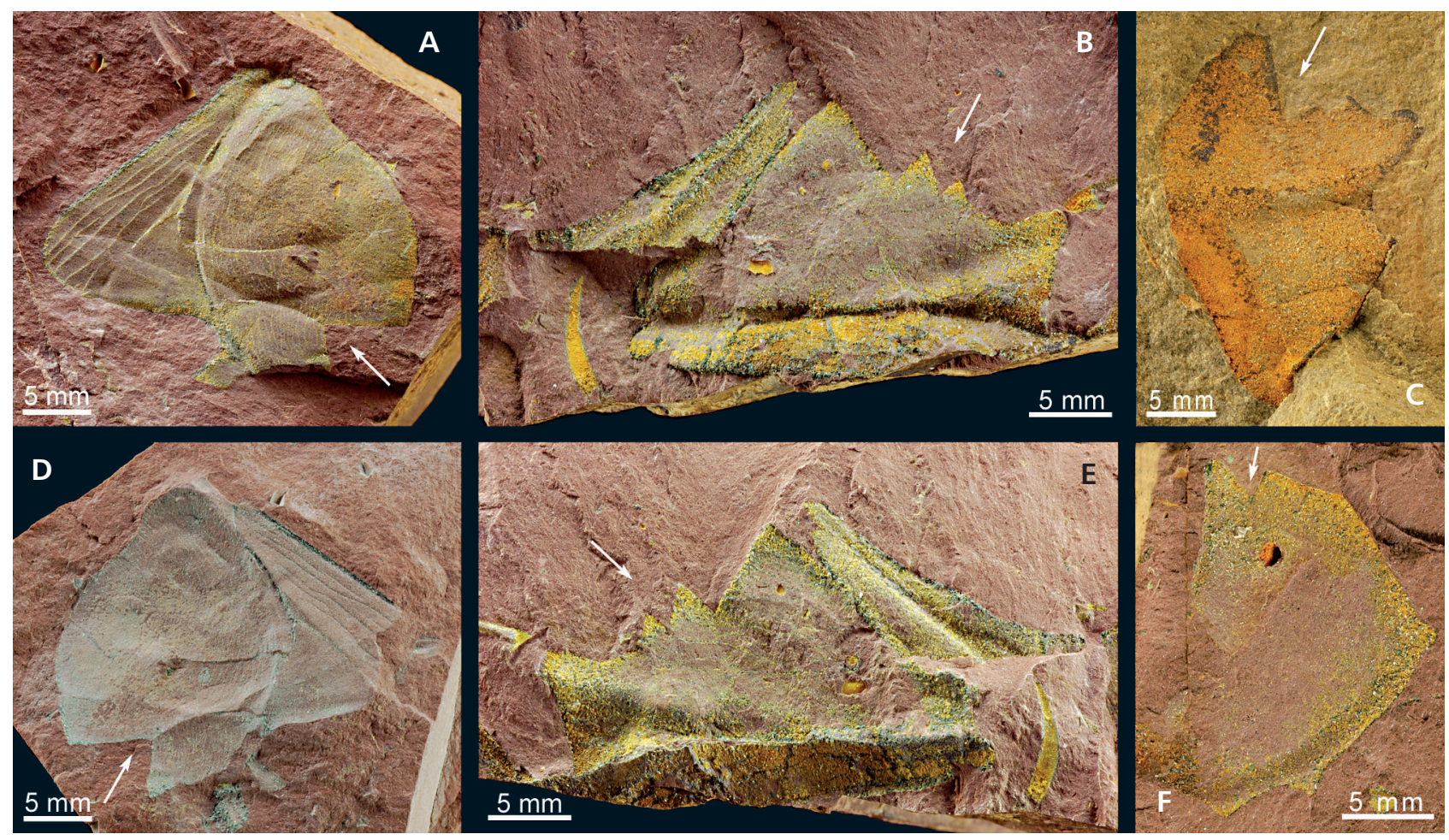

Figure 2. Mandibulichnus serratus nov. ichnogen., nov. ichnosp. • A, D - part and counterpart of a paradoxidid cranidium with a V-shaped serrated margin on the posterior part of the glabella. Specimen MPZ 2010/922 (paratype). B , E - holotype specimen (MPZ 2010/923). Part and counterpart of a paradoxidid librigena? with a complex W-shaped serrated margin. $\bullet \mathrm{C}$ - fragment of a paradoxidid cranidium showing a complex serrated margin. Specimen MPZ 2010/924 (paratype). • F - undetermined paradoxidid fragment with a simple V-shaped serration on the inner margin. Specimen MPZ 2010/925 (paratype).

\section{Serrated breakages}

Description. - Serrated margins occur on several incomplete, isolated paradoxidid sclerites (Fig. 2), namely cranidia, hypostomes and free cheeks. These serrations consist of straight segments of varying lengths arranged at angles between $55^{\circ}$ and $127^{\circ}$ (1.3-4.2 mm wide, between apices) (Fig. 3). As a result, they range in shape from broadly rounded to V-shaped (a single peak), W-shaped or even more complex. The general (or first order) path of the serrated margins is more or less straight, but can occasionally be slightly arcuate.

Discussion. - Several previous studies have reported serrated margins, but only a few of these are recorded on isolated sclerites (see Owen \& Bruton 1980, Pratt 1998 for examples). Since scars on complete specimens with evidence of regeneration are more notable, they have been described in greater detail in the literature. Bergström \& Levi-Setti (1978) described a single complete specimen of the middle Cambrian trilobite Paradoxides davidis showing lateral abnormalities in the thorax. Rudkin (1979) described four specimens of Ogygopsis klotzi displaying wounds with signs of external repair. Babcock (1993) reported complete specimens of the middle Cambrian trilobi- tes Elrathia kingii and Bathyuriscus elegans with indented thoraxes showing evidence of regeneration. Nedin (1999) described similar cases in the lower Cambrian trilobite Redlichia takooensis and in the non-mineralized arthropod Naraoia.

Babcock (2003) suggested that the presence of generally acute to triangular or asymmetrical W-shaped excisions is indicative of injuries related to predatory attacks. In many of these cases, malformations are thought to be the result of anomalocaridid bites (Babcock 1993, Nedin 1999). Nearly all of the examples described in Babcock (2003) are from complete specimens, and likely represent non-lethal predation because there are signs of repair on the trilobite exoskeleton. The ability of anomalocaridids to predate trilobites and other arthropods with highly mineralized cuticles has recently been questioned based on computer reconstruction and interpretation of the physical properties of anomalocaridid mouths (Hagadorn 2009), but this interpretation conflicts with direct evidence from the fossil record (Nedin 1999).

Breakages on isolated sclerites could well be more common in the fossil record, but as they are less noticeable than scars on complete specimens, they might not have been described in many cases. The cases we describe occur on isolated sclerites and do not follow lines of presumed 
Table 2. List of specimens with shortened pleural spines.

\begin{tabular}{|c|c|c|}
\hline Repository number & Position of shortened pleural spine & Figure \\
\hline MPZ2006/ 375 & Right first segment & Fig. $4 \mathrm{~A}-\mathrm{C}$ \\
\hline MPZ2006/ 375 & Left third segment & Fig. 4A, D, E \\
\hline MPZ2010/ 936 & $\begin{array}{l}\text { Left second segment from the } \\
\text { pygidium }\end{array}$ & Fig. 4F, I \\
\hline MPZ2010/ 936 & $\begin{array}{l}\text { Left third segment from the } \\
\text { pygidium }\end{array}$ & Fig. 4F, I \\
\hline MPZ2010/ 937 & $\begin{array}{l}\text { Left third segment from the } \\
\text { pygidium }\end{array}$ & Fig. 4G, J \\
\hline MPZ2010/ 938 & $\begin{array}{l}\text { Right third segment from the } \\
\text { pygidium }\end{array}$ & Fig. $4 \mathrm{H}, \mathrm{K}$ \\
\hline
\end{tabular}

weakness in the exoskeleton (i.e. glabellar furrows, eye socle furrow, etc.). Because they do not display exactly the same morphology as that observed in complete specimens, and are only present in isolated sclerites, they are difficult to correlate with an anomalocaridid bite. Breakage induced by physical processes is also rejected because taphonomic experiments suggest that it is almost impossible to break the arthropod cuticle through ordinary mechanical action (Pratt 1998, Babcock pers. com. 2010). The only plausible alternative is that these breakages were inflicted by a durophagous organism, either a scavenger or predator as has been proposed for several well studied examples in North America (Pratt 1998). The absence of potential predators/scavengers (with the possible exception of Eccaparadoxides sensu Fortey \& Owens, 1999, p. 463) in the same level as these sclerites means that it is highly speculative to correlate these breakages with the actions of any non-trilobite arthropod.

From an ichnological perspective, it seems feasible to unite both types of trilobite exoskeletal breakages (scars on the margins of complete specimens and serrated margins of isolated sclerites) under a common new ichnogenus (see the formal definition below), since they both indicate biting behaviour and share a common type of substrate consistency and geometry (bidimensional). Moreover, the new ichnogenus could be used to account for biting breakages on any bidimensional skeletal remains (not only for trilobites, but also for other groups).

\section{Shortened pleural spines}

Description. - Several complete or nearly complete specimens of Eccaparadoxides display shortened pleural spines with either normal or abnormal growth paths (Fig. 4).

In one case, a complete specimen of Eccaparadoxides sequeirosi (Fig. 4A-E; also reported by Liñán et al. 2008, fig. 20) shows two shortened pleural spines corresponding to the first right and $3^{\text {rd }}$ left pleural spine. The first one is approximately $60 \%$ normal length, with the shortening af-

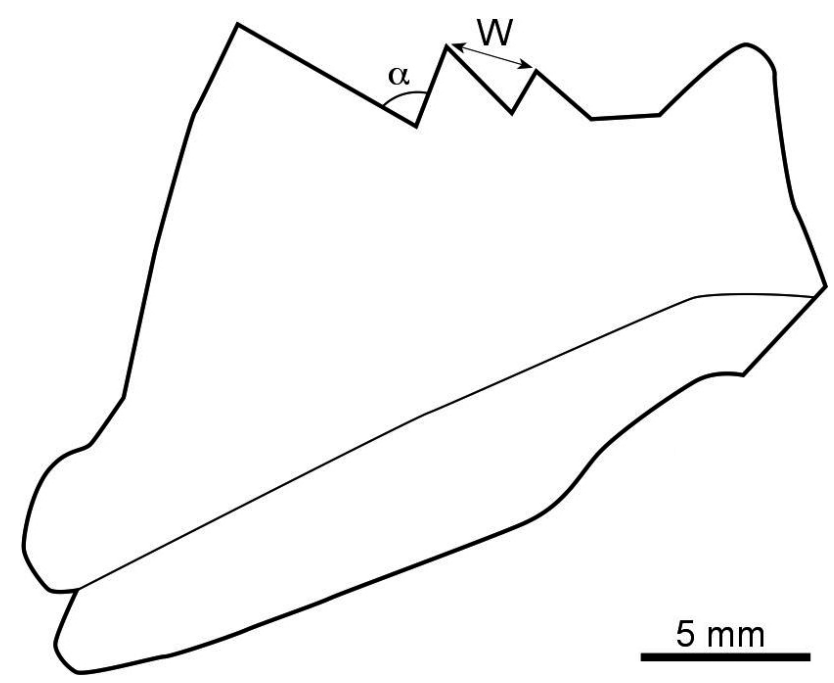

Figure 3. Camera lucida draw of the Mandibulichnus serratus nov. ichnogen. nov. ichnosp. holotype with the main measures taken.

fecting only the most distal part of the pleura (spine s.s.); the pleural furrow is well developed but the spine tip is forward-curved (abnormal growth path). In comparison to the corresponding pleura on the right side, the $3^{\text {rd }}$ left pleura is shortened by approximately 60-70\%, with shortening greatest in the distal part of the spine (spine s.s.); nevertheless, the pleural furrow is well developed, and the growth path and width are normal.

A second example occurs on a specimen of Eccaparadoxides pradoanus (Fig. 4G, J) with a complete thorax and pygidium. It has one shortened pleural spine in the posterior left side of the thorax (third pleural segment starting from the posterior part of the thorax), which is $40 \%$ normal length. It also shows the same growth as the normal pleural spines.

A third case is represented by a specimen of E. pradoanus (probably complete, but with the cephalon folded and consequently hidden within the matrix) (Fig. 4F, I) with two shortened pleural spines in the posterior left of the thorax $\left(2^{\text {nd }}\right.$ and $3^{\text {rd }}$ pleural spines from the posterior end). The $2^{\text {nd }}$ pleural spine is $c a 40 \%$ normal length and the $3^{\text {rd }}$ about one half the size of the corresponding right pleura.

The fourth case is a fully enrolled specimen of E. pradoanus (Fig. $4 \mathrm{H}, \mathrm{K}$ ) with the third right pleural spine (from the rear) shortened to $40 \%$ of full length, but showing a normal growth path.

Discussion. - Other trilobites show more substantially shortened pleural spines than what is observed in our paradoxidids. Owen (1985) commented that in some specimens shortened pleural spines are associated with mechanical breakage, cicatrisation, callusing and/or fusion of adjacent pleurae, and attributed these to injuries incurred during the 
moulting process. Budil et al. (2010, fig. 4A-C) figured a specimen of Areiaspis barrandei from the Middle Ordovician of the Barrandian area in which the $9^{\text {th }}$ left pleural spine is half the normal size and shows a distal, false "pleural furrow". These authors suggest that this malformation could correspond to an injury produced by a predatory attack, or be related to the moulting process.

Owen (1985) indicated that in some cases there is no sharp morphological distinction between shortened pleurae resulting from injuries and teratological conditions. None of the injury-related malformations (such as callusing, pleural fusion, and a false "pleural furrow") described in Owen (1985) or Budil et al. (2010) have been observed in our specimens. In our case study we simply observe short pleural spines, without any evidence of mechanical breakage and cicatrisation. Therefore, our specimens are probably not related to the moulting process or any other traumatic injury. Possible explanations include an inherited teratological shortening, or a malformation produced in the earliest larval stages with recuperation of normal pleural growth (with the exception of size) in subsequent moults. Among the four types of adaptation to injury by living animal cells, our cases of shortened pleural spines probably represent atrophy, which refers to a decrease in the size of cells, expressing in turn a smaller size in the affected tissue and presumably in the biomineralized sclerites secreted by those tissues (Purtilo 1978, Rudkin pers. com. 2011).

Only three specimens out of the 453 articulated paradoxidids collected in level number 10 of the Purujosa 3 section show shortened pleural spines. In two cases, these are located in the posterior part of the thorax; in only a single instance are two (adjacent) pleural spines affected. These data are indicative of how rare (in our sample less than $1 \%$ of individuals) shortened pleural spines are in the trilobite fossil record.

\section{Systematic palaeoichnology}

\section{Mandibulichnus nov. ichnogen.}

Type ichnospecies. - Mandibulichnus serratus nov. ichnosp.

Derivation of name. - From Latin mandibula $=$ jaw.
Diagnosis. - Bioerosion trace fossils consisting of marginal breakages on bidimensional, biomineralized skeletons or sclerites. Breakage shape ranges from straight to wavy (and intermediate forms), while the geometric pattern ranges from serrated to jagged or quite irregular. The general (first order) path of the trace is also variable.

Remarks. - The ichnogenus is interpreted as a biting trace, produced either during predation or scavenging. Shape and orientation of the breakages are variable, presumably because they correspond to different biting techniques and jaws (or raptorial appendages), though they all record a biting behaviour and share a common type of substrate consistency and geometry (bidimensional skeletons). They can be found either on complete skeletons or on single sclerites of trilobites and other groups.

Biting and gnawing traces made on bones (see Mikulás et al. 2006 and references therein) are quite different in shape (pits, grooves, striae, and fractures) and patterns to those of Mandibulichnus, since both are produced on substrates which greatly differ in consistency and geometry.

\section{Mandibulichnus serratus nov. ichnosp.} Figure 2

1998 Healed injury, cicatrized edge of exoskeleton - Pratt, p. 73 , fig. $1 \mathrm{~B}$.

? 1998 Healed injury, cicatrized edge of exoskeleton - Pratt, pp. $79,80,83$, figs $10 \mathrm{C}, 13 \mathrm{D}$.

Derivation of name. - From Latin serratus $=$ serrated.

Type locality. - Purujosa (Zaragoza province), NE Spain.

Type horizon. - Purujosa 3 section, characterized by green and red shales of the Murero Formation. These levels correspond to the Lower Caesaraugustan through the Lower Languedocian in the Mediterranean Cambrian subdivision.

Type material. - Specimen number MPZ 2010/923 is considered the holotype. Additional specimens MPZ 2010/922, 924, and 925 are paratypes. They are housed in the Museo Paleontológico de la Universidad de Zaragoza, Spain.

Figure 4. Shortened pleural spines. $•$ A-E - complete specimen of Eccaparadoxides sequeirosi (MPZ 2006/375) with single shortened pleural spine on the left and right anterior part of the thorax (note the irregular growth path of the shortened pleural spine). $\bullet$ F, I - internal mould of specimen of E. pradoanus (MPZ 2010/936) with two shortened pleurae on the posterior left side of the thorax. • G, J - external mould of a specimen of E. pradoanus (MPZ MPZ 2010/937) with one shortened pleura on the posterior left side of the thorax. • H, K - enrolled specimen of E. pradoanus (MPZ MPZ 2010/938) with one shortened pleura on the posterior right side of the thorax. 
Samuel Zamora et al. • Exoskeletal abnormalities in Cambrian paradoxidid trilobites

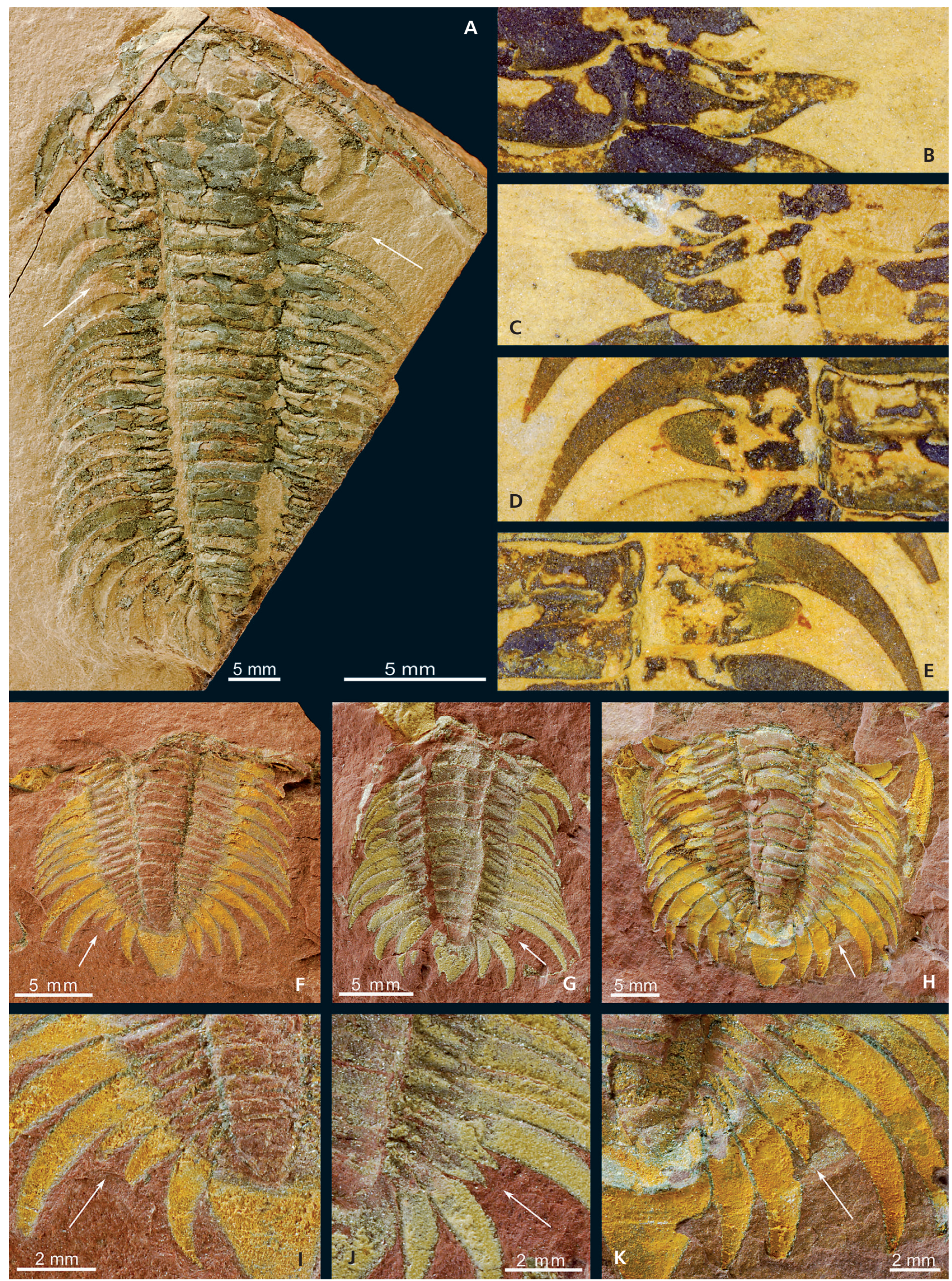


Diagnosis. - Serrated Mandibulichnus. Breakages consist of straight segments of variable length which join at variable angles, depicting somewhat variable morphologies tending to a V-shaped or asymmetrical W-shaped pattern (serrated pattern). The first order path of the trace is more or less straight, yet sometimes is slightly arcuate.

Description. - Mandibulichnus present on our material shows a marked, serrated outline with a high variable segment length (approximately $0.7 \mathrm{~mm}$ to $2.8 \mathrm{~mm}$ on the short side and $0.8 \mathrm{~mm}$ to $8 \mathrm{~mm}$ on the long side of the $\mathrm{V}$-segments) and angle (between $55^{\circ}$ and $127^{\circ}$ ). The largest and most complex specimen is approximately $18 \mathrm{~mm}$ in overall length and $4.3 \mathrm{~mm}$ "deep".

Remarks. - These serrated margins are interpreted as injuries inflicted by predators, or as breakages resulting from scavenging on carcasses. They could have been produced by either jaws or raptorial appendages. The margins have a consistent outline, generally $\mathrm{V}$ - or $\mathrm{W}$-shaped, but sometimes with somewhat rounded margins. In our material, they are found on isolated trilobite sclerites only, such as cranidia, librigenae and one hypostome. Biting traces of this type indicate that the predator was able to crush trilobites despite their thick-walled exoskeleton.

The identity of the producer of Mandibulichnus serratus nov. ichnosp. is unknown. No fossil remains of potential predators/scavengers were found in the studied beds, thus any suggestions would be highly speculative. Nevertheless, similar ichnofossils described by Pratt (1998) from the Upper Cambrian of northwestern Canada were suggested to be produced by arthropods similar to Yohoia.

\section{Conclusions}

Abnormalities in the exoskeletons of trilobites are generally rare, but when large collections of material are available for study, they can be identified. We provide an example from the Murero Formation (Spain) where the high abundance of trilobite fossils allows us to map different types of abnormalities. Two types have been identified: serrated margins on isolated sclerites and shortened pleural spines. The serrated marks are interpreted as biological in nature, supporting previous suggestions that organisms played an important role in fragmenting bioclasts in these kinds of environments. Lethal predation or scavenging processes are the most plausible explanations, but the identity of the predator/scavenger is unknown. The new ichnogenus Mandibulichnus and ichnospecies M. serratus are erected to describe scars or breakages showing asym- metrical $\mathrm{V}$ - or $\mathrm{W}$-shaped marks, attributed to biting behaviour (Mordichnia).

The other reported skeletal abnormalities are shortened pleural spines, located in the anterior or posterior most parts of the thorax, which show a normal growth path and are without associated callusing, fusion or any other malformation. These examples are very rare and probably represent atrophy related to genetic causes or damage in very early ontogenetic stages. As they are located in the most distal portions of the thoracic segments and presumably did not affect important organs, paradoxidids were able to survive with these types of abnormalities.

\section{Acknowledgements}

This paper is a contribution to the Project Consolíder number CGL2006-12975/BTE, "MURERO", from the Ministerio de Ciencia e Innovación of Spain and FEDER of the European Union. The comments from two reviewers, Petr Budil (Czech Geological Survey) and David Rudkin (Royal Ontario Museum), greatly improved the manuscript. Isabel Pérez (MEC-European Social Fund-Universidad de Zaragoza) provided us excellent photographic assistance. S.Z. acknowledges a postdoctoral fellowship from the Ministerio de Educación of Spain. J.E. has a pre-doctoral research grant from the Ministerio de Educación of Spain. A.S. and J.A.G.V. receive financial support from the Ministerio de Ciencia e Innovación of Spain in the form of "Juan de la Cierva" contracts (references JCI-2008-02431 and JCI-2009-05319). E.M. and A.S. also benefited from financial support provided by the Junta de Andalucía (Spain) to the Research Group RNM 316 ("Tectonics and Palaeontology"). We appreciate useful discussions on trilobite malformations with Loren Babcock (The Ohio State University, USA). Imran Rahman (University of Birmingham) reviewed the English of this paper and also improved it through useful scientific discussions.

\section{References}

AbrÀmoff, M.D., Margalhães, P.J. \& Ram, S.J. 2004. Image processing with ImageJ. Biophotonics International 11, $36-42$.

Álvaro, J.J. \& VizCAÏNO, D. 1998. Revision biostratigraphique du Cambrien moyen du versant méridional de la Montagne Noire (Languedoc, France). Bulletin de la Société Géologique de France 169, 233-242.

Álvaro, J.J. \& Vennin, E. 1997. Episodic development of Cambrian eocrinoid-sponge meadows in the Iberian Chains (NE Spain). Facies 37, 49-64. DOI 10.1007/BF02537370

Álvaro, J.J., Bauluz, B., Pierre, C., Subías, I. \& Vizcaïno, D. 2008. Carbon chemostratigraphy of the Cambrian-Ordovician transition in a midlatitude mixed platform, Montagne Noire, France. Geological Society of America Bulletin 120, 962-975. DOI 10.1130/B26243.1 
BABCOCK, L.E. 1993. Trilobite malformations and the fossil record of behavioral asymmetry. Journal of Paleontology 67(2), 217-229.

BABCock, L.E. 2003. Trilobites in Paleozoic predator-prey systems, and their role in reorganization of Early Paleozoic ecosystems, 55-92. In Kelley, P.H., KowalewsKi, M. \& HANSEN, T.A. (eds) Predator-Prey Interactions in the Fossil Record. Kluwer Academic/Plenum Publishers, New York.

BABCOCK, L.E. \& RoBISON, R.A. 1989. Preferences of Palaeozoic predators. Nature 337, 697-698. DOI 10.1038/337695c0

Bergström, J. \& LeVI-Setti, R. 1978. Phenotypic variation in the middle Cambrian trilobite Paradoxides davidis Salter at Manuels, SE Newfoundland. Geologica et Palaeontologica $12,1-40$.

Briggs, D.E.G. \& MounT, J.D. 1982. The occurrence of the giant arthropod Anomalocaris in the Lower Cambrian of southern California, and the overall distribution of the genus. Journal of Paleontology 56(5), 1112-1118.

Budil, P., FatKa, O., Zwanzig, M. \& RaK, Š. 2010. Two unique Middle Ordovician trilobites from the Prague Basin, Czech Republic. Journal of the National Museum (Prague), Natural History Series 179, 95-104.

Daley, A.C., Budd, G.E., Caron, J.B, Edgecombe, G.D. \& ColLINs, D. 2009. The Burgess Shale anomalocaridid Hurdia and its significance for early euarthropod evolution. Science 20, 1597-1600. DOI 10.1126/science.1169514

Esteve, J., Hughes, N.C. \& Zamora, S. 2011. Purujosa trilobite assemblage and the evolution of trilobite enrollment. Geology 6, 575-578. DOI 10.1130/G31985.1

FatKa, O., SzaBAD, M. \& Budil, P. 2009. Malformed agnostids from the Middle Cambrian Jince Formation of the PríbramJince Basin, Czech Republic. Bulletin of Geosciences 83(1), 121-126. DOI 10.3140/bull.geosci.1107

Fortey, R.A. \& Owens, R.M. 1999. Feeding habits in trilobites. Palaeontology 42, 429-465. DOI 10.1111/1475-4983.00080

GÁmeZ Vintaned, J.A., Schmitz, U. \& LiÑán, E. 2009. Upper Vendian-lowest Ordovician sequences of the western Gondwana margin, NE Spain, 231-244. In Craig, J., Thurow, J., Thusu, B., Whitham, A. \& Abutarruma, Y. (eds) Global Neoproterozoic petroleum systems: the emerging potential in North Africa. Geological Society of London, Special Publications 326. DOI 10.1144/SP326.13

Gozalo, R., Chirivella Martorell, J.B., Esteve, J. \& Liñán, E. 2011. Correlation between the base of Drumian Stage and the base of middle Caesaraugustan Stage in the Iberian Chains (NE Spain). Bulletin of Geosciences 86(3), 545-554. DOI 10.3140/bull.geosci.1254

Hagadorn, J.W. 2009. Taking a bite out of Anomalocaris. Walcott 2009 - International Conference on the Cambrian Explosion, Abstract Volume, 33-34, http://burgess-shale.info/abstract/hagadorn.

Hutchinson, G.E. 1961. The biologist poses some problems, 85-94. In SEARs, M. (ed.) Oceanography. Invited lectures presented at the $1^{\text {st }}$ International Oceanographic Congress, New York, 1959. American Association for the Advancement of Science Publication 67.

Liñán, E., Gozalo, R., Dies, M.E., Gámez Vintaned, J.A., Mayoral, E., Chirivella, J., Esteve, J., Zamora, A., Zhuravlev,
A.Y. \& ANDRÉs, J.A. 2008. Fourth International Trilobite Conference, Trilo 08. Toledo, Spain, 2008. Post-Conference Field Trip. Lower and Middle Cambrian trilobites of selected localities in Cadenas Ibéricas (NE, Spain). 52 pp. Universidad de Zaragoza, Zaragoza.

Liñán, E., Gozalo, R., Palacios, T., Gámez Vintaned, J.A., Ugidos, J.M. \& Mayoral, E. 2002. 3. Cambrian, 17-29. In Gibbons, W. \& Moreno, T. (eds) The geology of Spain. The Geological Society, London.

Mikuláš, R., Kadlecová, E., Fejfar, O. \& Dvořák, Z. 2006. Three new ichnogenera of biting and gnawing traces on reptilian and mammalian bones: a case study from the Miocene of the Czech Republic. Ichnos 13, 113-127. DOI 10.1080/10420940600850729

Nedin, C. 1999. Anomalocaris predation on nonmineralized and mineralized trilobites. Geology 27, 987-990. DOI 10.1130/0091-7613(1999)027<0987:APONAM>2.3.CO;2

Owen, A.W. 1985. Trilobite abnormalities. Transactions of the Royal Society of Edinburgh 76, 255-272.

Owen, A.W. \& Bruton, D.L. 1980. Late Caradoc-early Ashgill trilobites of the central Oslo Region, Norway. Palaeontological Contributions from the University of Oslo 245, 1-63.

PratT, B.R. 1998. Probable predation on Upper Cambrian trilobites and its relevance for the extinction of soft-bodied Burgess Shale-type animals. Lethaia 31, 73-88. DOI 10.1111/j.1502-3931.1998.tb00493.x

Purtilo, D.T. 1978. A survey of human diseases. 453 pp. Addison-Wesley, Menlo Park, California.

Rudkin, D.M. 1979. Healed injuries in Ogygopsis klotzi (Trilobita) from the Middle Cambrian of British Columbia. Royal Ontario Museum, Life Sciences Occasional Paper 32, 1-8.

RudKIN, D.M. 1985. Exoskeletal abnormalities in four trilobites. Canadian Journal of Earth Sciences 22, 479-483.

ŠNAJDR, M. 1978. Anomalous carapaces of Bohemian paradoxid trilobites. Sborník geologických věd 20, 7-28.

ŠNAJDR, M. 1979. Two trinucleid trilobites with repair of traumatic injuries. Věstník Ústředního ústavu geologického 54, 49-51.

ŠNAJDR, M. 1990. Bohemian trilobites. 265 pp. Ústřední ústav geologický, Praha.

Vannier, J., García-Bellido, D.C., Hu, S.-X \& Chen, A.-L. 2009. Arthropod visual predators in the early pelagic ecosystem: evidence from the Burgess Shale and Chengjiang biotas. Proceedings of the Royal Society B 276, 1567-2574. DOI 10.1098/rspb.2009.0361

VermeIJ, G.V. 1989. The origin of skeletons. Palaios 4, 585-589. DOI $10.2307 / 3514748$

ZAMORA, S. 2010. Middle Cambrian echinoderms from North Spain show echinoderms diversified earlier in Gondwana. Geology 38(6), 507-510. DOI 10.1130/G30657.1

Zamora, S. \& Álvaro, J.J. 2010. Testing for a decline in diversity prior to extinction: Languedocian (latest mid-Cambrian) distribution of cinctans (Echinodermata) in the Iberian Chains, NE Spain. Palaeontology 53, 1349-1368. DOI 10.1111/j.1475-4983.2010.01004.x

ZAMORA, S. \& SMith, A.B. 2010. The oldest isorophid edrioasteroid (Echinodermata) and the evolution of attachment strategies in Cambrian edrioasteroids. Acta Palaeontologica Polonica 53(3), 487-494. DOI 10.4202/app.2010.0012 